\title{
PERLINDUNGAN HAK ANAK DALAM PAGAKSANAAN PROGRAM IMUNISASI DI KABUPATEN KARANGANYAR (Kajian Kasus Penolakan Imunisasi Anak Di Kabupaten Karanganyar)
}

\author{
Dwi Rusharyati \\ e-mail : roesharyati@gmail.com \\ Pegawai Dinas Kesehatan Karanganyar \\ W.T Novianto \\ e-mail: novianto@consultant.com \\ Dosen Fakultas Hukum UNS \\ Moch. Najib Imanullah \\ e-mail: najibimanullah@staff.uns.ac.id \\ Dosen Fakultas Hukum UNS
}

\begin{abstract}
This article aims to explain the causes of the rejection of child immunization and efforts should be made so that the implementation of the childhood immunization program is well received in the protection of the rights of children in Karanganyar. This type of research is empirical. Form of research is exploratory. The data used are primary data and secondary data collection methods of documentation and interviews. Analysis of data using qualitative analysis. Based on the description of the results of research and discussion in connection with the considered problem with the theory of the legal system and application of the theory of law, it can be concluded that the factors that led to the rejection of immunization is: (a) the legal structure has not been able to implement the rules contained in the law; (b) legal norm or rule can not be implemented fully in society; (c) Most people do not understand the law and legal content community do not know the benefits of the existing law. Efforts should be made so that the implementation of the childhood immunization program is well received by all communities in Karanganyar district are: (a) the legal structure should be addressed; (b) The public policy context with the real conditions in the field or community legal norms or rules that can be applied; (c) promoting positive law and the laws governing the contents of the immunization program to the public so that people understand them. As for the consequences of the legal system are not addressed, then the rejection of child immunization will still occur and may tend to increase. The rights of children to be immunized and the rights of children born to avoid the diseases that threaten the survival and/or cause disability unprotected
\end{abstract}

Keywords: Legal Protection; Rights of the Child; Immunization Program.

\begin{abstract}
Abstrak
Artikel ini bertujuan menjelaskan faktor penyebab terjadinya penolakan imunisasi anak dan upaya yang harus dilakukan agar pelaksanaan program imunisasi anak dapat diterima dengan baik dalam upaya perlindungan hak-hak anak di Kabupaten Karanganyar. Jenis penelitian adalah empiris. Bentuk penelitian adalah eksploratif. Data yang digunakan adalah data primer dan data sekunder dengan metode pengumpulan data dokumentasi dan wawancara. Analisis datanya menggunakan analisis kualitatif. Berdasarkan deskripsi hasil penelitian dan pembahasan sehubungan dengan masalah yang dikaji dengan teori sistem hukum dan teori penerapan hukum, dapat disimpulkan
\end{abstract}


bahwa faktor yang menyebabkan terjadinya penolakan imunisasi adalah : (a) Struktur hukumnya belum mampu melaksanakan aturan yang ada dalam hukum; (b) Norma atau aturan hukumnya belum dapat diterapkan sepenuhnya di masyarakat; (c) Sebagian masyarakat belum memahami hukum dan isi hukum sehingga masyarakat belum mengetahui manfaat dari hukum yang ada. Upaya yang harus dilakukan agar pelaksanaan program imunisasi anak dapat diterima dengan baik oleh semua masyarakat di Kabupaten Karanganyar adalah : (a) struktur hukumnya harus dibenahi; (b) Adanya kebijakan publik yang lebih kontekstual dengan kondisi riil di lapangan atau masyarakat sehingga norma atau aturan hukumnya dapat diterapkan; (c) mensosialisasikan hukum positif dan isi hukum yang mengatur tentang program imunisasi kepada masyarakat sehingga masyarakat memahaminya. Adapun konsekuensi apabila sistem hukumnya tidak dibenahi, maka penolakan imunisasi anak akan tetap terjadi dan mungkin cenderung meningkat. Hak anak untuk mendapatkan imunisasi dan hak anak yang lahir terhindar dari penyakit yang mengancam kelangsungan hidup dan/atau menimbulkan kecacatan belum terlindungi.

Kata kunci: Perlindungan Hukum: Hak Asasi Anak; Program Imunisasi.

\section{A. Pendahuluan}

Kesehatan merupakan hak asasi manusia dan salah satu unsur kesejahteraan yang harus diwujudkan sesuai dengan cita-cita bangsa Indonesia sebagaimana dimaksud dalam Pancasila dan Undang-Undang Dasar Negara Republik Indonesia Tahun 1945. Kesehatan sebagai hak asasi manusia harus diwujudkan dalam bentuk pemberian berbagai pelayanan kesehatan yang berkualitas. Pelayanan kesehatan meliputi pelayanan kesehatan perorangan dan pelayanan kesehatan masyarakat. Untuk meningkatkan derajat kesehatan masyarakat dan mempertahankan status kesehatan seluruh rakyat Indonesia diperlukan tindakan imunisasi sebagai tindakan preventif.

Dalam dunia kesehatan dikenal tiga pilar utama dalam meningkatkan kesehatan masyarakat, yaitu preventif atau pencegahan, kuratif atau pengobatan dan rehabilitatif atau pemulihan. Imunisasi merupakan suatu upaya pencegahan primer guna menghindari terjadinya sakit atau kejadian yang dapat mengakibatkan seseorang sakit atau menderita cedera dan cacat.

Imunisasi merupakan program jangka panjang, kurang lebih sudah mencapai
20 tahun. Imunisasi telah dirancang lama termasuk pembuatan vaksin. Hal tersebut berdasarkan pada landasan hukum UndangUndang Dasar Tahun 1945. Pasal 28 B ayat (2) disebutkan "Setiap anak berhak atas kelangsungan hidup, tumbuh dan berkembang, serta berhak atas perlindungan dari kekerasan diskriminasi" Pasal $28 \mathrm{H}$ ayat (1) "Setiap orang berhak atas sejahtera lahir dan batin, bertempat tinggal dan mendapat lingkungan hidup yang baik dan sehat serta berhak memperoleh pelayanan kesehatan".

Pemerintah wajib memberikan imunisasi lengkap kepada setiap bayi dan anak. Setiap anak berhak memperoleh imunisasi dasar sesuai dengan ketentuan yang berlaku untuk mencegah terjadinya penyakit yang dapat dihindari melalui imunisasi. Dalam UndangUndang Nomor 35 Tahun 2014 tentang Perlindungan Anak disebutkan bahwa Negara, Pemerintah, Pemerintah Daerah, keluarga dan orang tua wajib mengusahakan agar anak yang lahir terhindar dari penyakit yang mengancam kelangsungan hidup dan/atau menimbulkan kecacatan.

Upaya imunisasi diselenggarakan di Indonesia sejak tahun 1956. Di Indonesia, Program Imunisasi Nasional dikenal sebagai 
Pengembangan Program Imunisasi (PPI) yang dilaksanakan sejak tahun 1977. Imunisasi yang termasuk dalam PPI adalah Hepatitis B, BCG, Polio, DTP, HIB dan Campak. Program Imunisasi Nasional disusun berdasarkan keadaan epidemiologi penyakit yang terjadi saat itu. Maka jadwal program imunisasi dapat berubah dari tahun ke tahun.

Program imunisasi merupakan program pelayanan kesehatan yang wajib disediakan dan diselenggarakan pemerintah. Istilah wajib karena program imunisasi merupakan pelayanan yang domain rendah dan memiliki dampak terhadap orang lain (externality) yang besar. Pemerintah harus menyediakan tenaga yang andal dan cukup dalam melakukan imunisasi, alat cukup sesuai standar teknis, dana cukup dan vaksin yang cukup.

Penyelenggaraan program imunisasi di Indonesia juga mengacu pada kesepakatankesepakatan internasional. WHO pada tahun 1988 dan UNICEF melalui World Summit for Children pada tahun 1990 tentang ajakan untuk mencapai target cakupan imunisasi, Eliminasi Tetanus Neonatorum dan Reduksi Campak. Himbauan dari WHO bahwa negara dengan tingkat endemisitas tinggi pada tahun 1997 diharapkan telah melaksanakan program imunisasi hepatitis B ke dalam program imunisasi rutin.

Manfaat imunisasi yaitu pertahanan tubuh yang dibentuk oleh beberapa vaksin akan dibawa seumur hidup, cost effective karena murah dan efektif dan tidak berbahaya (reaksi serius sangat jarang terjadi, jauh lebih jarang daripada komplikasi yang timbul apabila terserang penyakit tersebut secara alami). Imunisasi juga memiliki dampak secara individu, sosial dan epidemiologi. Imunisasi menurunkan angka kesakitan sehingga akan turun pula biaya pengobatan dan perawatan di rumah sakit. Dengan imunisasi akan mencegah anak dari penyakit infeksi yang berbahaya berarti akan meningkatkan kualitas hidup anak dan meningkatkan daya produktifitas di kemudian hari.

Imunisasi selain bertujuan untuk mencegah penyakit bagi diri sendiri, juga dapat melindungi orang disekitarnya. Imunisasi memberikan kekebalan individu dan kelompok atau komunitas. Individu yang tidak diimunisasi dapat membahayakan individu yang diimunisasi. Semakin banyak yang tidak diimunisasi dalam suatu komunitas risiko penularan makin tinggi, bahkan yang sudah diimunisasi bisa tertular. Tujuan dari program imunisasi adalah: 1) Turunnya angka kesakitan, kecacatan dan kematian bayi akibat Penyakit yang Dapat Dicegah Dengan Imunisasi (PD3I); (2) Tercapainya Universal Child Immunization (UCI), yaitu cakupan imunisasi minimal $80 \%$ secara merata pada bayi di 100\% desa/kelurahan; (3) Tercapainya eliminisasi Tetanus Maternal dan Neonatal pada tahun 2005; (4) Tercapainya pemutusan rantai penularan Poliomyelitis serta sertifikasi bebas polio pada tahun 2008; (5) Tercapainya reduksi campak pada tahun 2005 .

Penyakit yang Dapat Dicegah Dengan Imunisasi (PD3I) seperti TBC, Diphteri, Pertusis, Campak, Tetanus, Polio dan Hepatitis B merupakan salah satu penyebab kematian anak di negara-negara berkembang termasuk Indonesia. Diperkirakan 1,7 juta kematian anak atau $5 \%$ pada bayi di Indonesia adalah akibat PD3I. Agar target nasional dan global untuk mencapai eradikasi, eliminasi dan reduksi terhadap PD3I dapat tercapai, cakupan imunisasi harus dipertahankan tinggi dan merata sampai mencapai tingkat Population Immunity (kekebalan masyarakat) yang tinggi. Kegagalan untuk menjaga tingkat cakupan imunisasi yang tinggi dan merata dapat menimbulkan Kejadian Luar Biasa (KLB) PD3I. Penyakit yang Dapat Dicegah Dengan Imunisasi (PD3I) termasuk jenis penyakit menular yang dapat menimbulkan wabah. 
Upaya penanggulangan wabah meliputi:(1) Penyelidikan epidemiologi; (2) Pemeriksaan, pengobatan, perawatan, dan isolasi penderita, termasuk karantina; (3) Pencegahan dan pengebalan; (4) Pemusnahan penyebab penyakit; (5) Penanganan jenazah akibat wabah; (6) Penyuluhan kepada masyarakat; (7) Upaya penanggulangan lainnya. Imunisasi termasuk upaya penanggulangan wabah dengan cara pencegahan dan pengebalan, sehingga diharapkan dengan diberikan imunisasi akan terhindar dari PD3I. Barang siapa dengan sengaja menghalangi pelaksanaan penanggulangan wabah sebagaimana diatur dalam Undang-Undang Nomor 4 Tahun 1984 tentang Wabah Penyakit Menular, diancam dengan pidana penjara selama-lamanya satu tahun dan/atau denda setinggi-tingginya satu juta rupiah.

Indonesia dua kali berhasil menghapuskan PD3I dari bumi Indonesia. Pertama dengan dihilangkannya penyakit cacar pada tahun 1974. Kedua, penyakit polio berhasil dieradikasi pada tahun 1995. Keberhasilan tersebut adalah upaya dan langkah panjang dalam membangun kesehatan Indonesia. Setelah berhasil menghilangkan polio dari bumi Indonesia, pada tahun 2005 terjadi Kejadian Luar Biasa (KLB) polio di Sukabumi. Setelah penyakit ini tak ditemukan lagi sejak tahun 1995, lima anak dinyatakan positif terserang virus polio. Hal tersebut diakibatkan masih ada anak-anak yang tidak diimunisasi dengan berbagai alasan. Selama tahun 2012 ditemukan 762 kasus penyakit difteri di Jawa Timur yang menyebabkan 29 penderita meninggal. Belum meratanya imunisasi DPTHB hingga ke pelosok membuat wabah ini sulit ditanggulanggi. Data Dinas Kesehatan Jatim, kasus difteri pada tahun 2012 meningkat dibanding dengan 2011 yang mencapai 664 kasus dan menyebabkan 20 meninggal. Mereka menetapkan status Kejadian Luar Biasa (KLB) sejak tahun 2011.
Di akhir abad ke-18 dilaporkan penyakit smallpox (variola atau cacar monyet) telah membunuh 400.000 warga eropa per tahunnya, yang sebagian besar adalah anak-anak. Bahkan diperkirakan sekitar 300-500 juta orang di abad ke-20 telah meninggal akibat penyakit smallpox. Selain memunculkan bopeng yang membuat penderitanya menjadi buruk rupa dan menyebabkan kematian, smallpox juga menyebabkan kebutaan serta penyakit tulang. Penyakit yang disebabkan oleh virus variola ini pun sangat mudah menular, hanya lewat udara, percikan ludah atau berdekatan saja, orang lain bisa tertular.

Pelaksanaan program imunisasi di Indonesia belum berjalan dengan maksimal, hal ini dikarenakan belum mencapai $100 \%$ usia imunisasi mendapatkan vaksin. Beberapa kendala memperngaruhi hal tersebut, diantaranya kendala geografis, azas prioritas, sekadar lupa dan bahkan ada komunitas atau sebagian masyarakat yang anti terhadap penggunaan vaksin. Komunitas atau masyarakat yang menolak vaksin atau imunisasi ini ada 3 kategori. Kategori (1) adalah masyarakat yang memiliki kecurigaan yang berlebihan kepada pemerintah, sistem kesehatan, dan bisnis farmasi. Kategori (2) merupakan masyarakat yang menolak imunisasi karena alasan keimanan, dilarang dalam kepercayaannya. Kategori (3) merupakan gabungan dari kategori (1) dan kategori (2).

Gerakan antivaksin ternyata tidak hanya terjadi di Indonesia, tapi juga di banyak negara. Di Kanada dilaporkan adanya sebagian masyarakat antivaksin. Sebagian masyarakat mempertanyakan validitas vaksinasi dengan alergen imunoterapi, yang kemudian memberikan panduan tentang bagaimana dokter bisa menanggapi kekhawatiran pasien terhadap alergen imunoterapi dalam pengaturan klinis. Negara Amerika Serikat sebagai negara yang maju juga ada gerakan antivaksin. Dalam 
suatu penelitian di Amerika mengemukakan bahwa masyarakat yang terpengaruh konspirasi antivaksin menunjukkan kurang niat dalam memberikan vaksinasi terhadap anaknya. Pada tahun 2010 di Amerika merebak kasus pertusis, beberapa sekolah harus ditutup dan setidaknya sepuluh bayi meninggal akibat merebaknya pertusis ini. Dan sejak tahun 2007, akibat gerakan antivaksin, telah terjadi 77.000 penyakit yang sebetulnya bisa dicegah. Dampak secara tidak langsungnya, gerakan antivaksinasi ini juga telah mengakibatkan 700 kematian dalam rentang tahun yang sama. Bukti-bukti ilmiah tentang manfaat vaksin sudah banyak. Beragam data terpercaya menunjukkan bila angka cakupan vaksinasi menurun maka wabah penyakit akan muncul. Bukti lain lagi terjadi pada merebaknya kasus campak di negara-negara dengan angka cakupan vaksinasi turun seperti di Perancis, Belgia, Jerman, Romania, Serbia, Spanyol, Macedonia dan Turkey. Di tahun 2011 juga terjadi 334 kasus campak di Inggris, padahal tahun sebelumnya hanya 33 kasus.

Pada akhir bulan Juni 2016, Indonesia dikejutkan dengan berita beredarnya vaksin palsu ditengah-tengah masyarakat. Kasus ini berawal dari adanya bayi yang meninggal pasca imunisasi dan dari hasil penyelusuran dan analisis fakta-fakta di lapangan ditemukan bahwa vaksin yang diberikan merupakan vaksin palsu yang berupa cairan infus dicampur dengan vaksin tetanus. Kasus tersebut menimbulkan keresahan di masyarakat. Masyarakat menjadi ragu-ragu untuk mengimunisasikan anaknya, mereka khawatir anaknya menjadi korban vaksin palsu. Di Kabupaten Karanganyar dalam menghadapi kasus vaksin palsu tersebut, segera mengambil langkah melakukan pengecekan persediaan vaksin di gudang dan vaksin yang digunakan difasilitas kesehatan. Dari hasil pengecekan tersebut, tidak ditemukan satupun vaksin palsu. Pemerintah Kabupaten Karanganyar melalui Dinas Kesehatan Kabupaten (DKK), memastikan jika bumi Intanpari bebas dari vaksin palsu.

Program imunisasi di Kabupaten Karanganyar dalam pelaksanaannya masih terjadi penolakan oleh sebagian masyarakat. Tren penolakan imunisasi pada anak di Kabupaten Karanganyar dari tahun ke tahun mengalami peningkatan. Penolakan tersebut banyak terjadi pada saat Pekan Imunisasi Nasional (PIN) yang dilaksanakan pada tanggal 8 Maret sampai dengan 15 Maret 2016 secara serentak. Berbagai upaya sudah dilakukan untuk mengatasinya, dari melakukan penyuluhan, pendekatan sampai dilakukan sweeping namun upaya tersebut belum memberikan hasil.

Data penolakan program imunisasi dasar di kabupaten Karanganyar tahun 2015 sejumlah 94 yang tersebar di sebelas kecamatan, kecamatan mojogedang 1 orang, kecamatan Jatiyoso 10 orang, kecamatan Jumapolo 5 orang, kecamatan Tawangmangu 49 orang, kecamatan Ngargoyoso 9 orang, kecamatan Karanganyar 1 orang, kecamatan Colomadu 3 orang, kecamatan Jenawi 4 orang, kecamatan Tasikmadu 1 orang, kecamatan Jaten 4 orang dan kecamatan Kebakkramat 2 orang. Data desa yang belum UCI ada 7 desa. Dari data tersebut menggambarkan bahwa anak yang berada pada desa non UCI mempunyai resiko tertular Penyakit yang Dapat Dicegah Dengan Imunisasi. Data penolakan program Imunisasi pada Pekan Imunisasi Nasional sejumlah 714 yang tersebar di enam belas kecamatan, kecamatan Jatipuro 1 orang, kecamatan Kebakkramat 14, kecamatan Kerjo 4 orang, kecamatan Colomadu 18 orang, kecamatan Jaten 24 orang, kecamatan Tasikmadu 16 orang, kecamatan Jumantono 18 orang, kecamatan Jumapolo 23 orang, kecamatan Karangpandan 27 orang, kecamatan Gondangrejo 27 orang, kecamatan Matesih 31 orang, kecamatan Jenawi 33 orang, kecamatan Jatiyoso 70 orang, kecamatan Ngargoyoso 80 orang, kecamatan Karanganyar 102 orang, dan 
kecamatan Tawangmangu 226 orang. Untuk mengetahui dan memecahkan permasalahan mengapa terjadi penolakan imunisasi inilah yang dibahas dalam artikel ini.

\section{B. Metode Penelitian}

Penelitian mengenai " Perlindungan Anak Dalam Pelaksanaan Program Imunisasi di Kabupaten Karanganyar" ini merupakan jenis penelitian empiris. Penelitian empiris yaitu suatu penelitian yang bertujuan untuk dapat melihat hukum dalam artian nyata serta meneliti bagaimana penerapan hukum di suatu lingkungan masyarakat. Sumber data dalam penelitian ini adalah data primer dan data sekunder dengan teknik pengumpulan data dokumentasi dan wawancara.

Teknik analisis data yang digunakan dalam penelitian ini adalah deskriptif kualitatif dengan tujuan mengungkap fakta dan keadaan yang terjadi saat penelitian dan menyuguhkan data apa adanya. Terdapat tiga teknik analisa data kualitatif yaitu reduksi data, penyajian data dan penarikan kesimpulan. Reduksi data adalah bentuk analisa yang menajamkan, menggolongkan, mengarahkan, membuang yang tidak perlu dan mengorganisasi data sedemikian rupa sehingga kesimpulan akhir dapat diambil. Penyajian data adalah kegiatan ketika sekumpulan informasi disusun sehingga memberi kemungkinan akan adanya penarikan kesimpulan. Bentuk penyajian data kualitatif berupa teks naratif. Penarikan kesimpulan adalah hasil analisis yang dapat digunakan untuk mengambil tindakan.

\section{Hasil Penelitian dan Pembahasan}

Berdasarkan penelitian dan pembahasan yang dilakukan maka dihasilkan hal-hal sebagai berikut :

Hasil penelitian yang dilakukan, sebagian besar responden menyatakan alasan penolakan imunisasi karena meragukan kehalalan vaksin yang digunakan dalam imunisasi dan sebagian responden lainnya menyatakan menggunakan alternatif lain dan khawatir anaknya sakit setelah diimunisasi. Berdasarkan hasil penelitian sebagian responden mengatakan belum pernah mendapatkan sosialisasi. Sosialisasi tentang imunisasi diberikan oleh pihak Puskesmas maupun Dinas Kesehatan dengan materi yang diberikan tentang manfaat imunisasi, sebagian besar responden belum mengetahui bahwa orangtua mempunyai kewajiban memberikan imunisasi dasar kepada anaknya dan tidak mengetahui bahwa ada sanksi hukum bagi masyarakat yang menolak melakukan imunisasi kepada anaknya. Masyarakat yang menolak imunisasi tidak mengetahui bahwa anak yang tidak diimunisasi akan membahayakan lingkungan disekitarnya yaitu kemungkinan adanya wabah. Masyarakat yang menolak imunisasi, sebagian besar menyatakan bahwa pemerintah harus memberi kejelasan terkait kehalalan vaksin yang digunakan dalam program imunisasi. Dan pemerintah harus melakukan sosialisasi yang lebih banyak lagi.

Masyarakat yang tidak menolak/menerima imunisasi, beralasan bahwa imunisasi sangat penting untuk kesehatan anak yaitu memberikan kekebalan pada anak dan juga karena imunisasi merupakan program dari pemerintah. Sebagian besar responden mengetahui manfaat dari pemberian imunisasi kepada anak. Masyarakat yang menerima program imunisasi ini, pernah mendapatkan sosialisasi. Sosialisasi diberikan oleh petugas kesehatan dari Puskesmas dan petugas dari Dinas Kesehatan Kabupaten. Materi sosialisasi meliputi manfaat dari imunisasi dan hal-hal lain terkait imunisasi. Hampir semua responden mengetahui bahwa sebagai orangtua wajib memberikan imunisasi dasar pada anaknya.

Faktor-faktor yang menyebabkan terjadinya penolakan terhadap program imunisasi di Kabupaten Karanganyar, dibahas 
dari faktor struktur hukum, substansi hukum dan kultur hukumnya.

Struktur hukum dari suatu sistem hukum mencakup berbagai institusi yang diciptakan oleh sistem hukum tersebut dengan berbagai macam fungsinya dalam mendukung bekerjanya sistem tersebut. Struktur hukum dalam pelaksanaan program imunisasi ini meliputi aparat pemerintah baik yang ada di kabupaten maupun di kecamatan. Aparat pemerintah sebagai penanggungjawab pelaksanaan program imunisasi di tingkat kabupaten terdiri dari Kepala Seksi Imunisasi, Kepala Bidang P2PL (Pengendalian Penyakit dan Penyehatan Lingkungan) dan Kepala Dinas Kesehatan Kabupaten. Penanggungjawab pelaksanaan program imunisasi di tingkat kecamatan adalah kepala puskesmas. Dalam program imunisasi yang sifatnya massal seperti kegiatan eradikasi polio strukturnya melibatkan lintas sektoral.

Penanggungjawab pelaksanaan program imunisasi belum mampu dalam menghadapi masalah penolakan imunisasi tersebut. Hal tersebut dikarenakan keterbatasan kewenangan yang dimilikinya. Penanggungjawab program imunisasi hanya sebatas memberikan himbauan kepada masyarakat yang menolak, membuat surat pertanyaan penolakan sebagai data pelaporan dan mensosialisasikan program imunisasi dengan melibatkan masyarakat dan lintas sektoral. Berdasarkan hasil penelitian, hal-hal yang menjadi penyebab yang paling dominan adalah masalah keyakinan, dimana masyarakat masih ragu terkait kehalalan vaksin yang dipakai dalam program imunisasi terhadap anak. Masalah halal dan haram bagi umat Islam merupakan sesuatu yang sangat penting.

Pada kasus penolakan imunisasi di kabupaten karanganyar ini belum ada sanksi hukum yang diberikan kepada orangtua yang menolak program imunisasi tersebut, karena penanggungjawab program imunisasi baik di tingkat kabupaten maupun di tingkat kecamatan tidak memiliki kewenangan menjatuhkan sanksi. Penerapan hukum salah satunya tergantung dari unsur stukturalnya. Stuktural merupakan lembaga-lembaga atau organisasi yang diperlukan dalam penerapan hukum. Lembaga atau penanggungjawab pelaksanaan program imunisasi sudah mengerti maksud dari aturan hukum tentang imunisasi yang ada, tetapi tidak mampu melaksanakannya karena keterbatasan kewenangan yang diberikan. Struktur hukum dalam pelaksanaan program imunisasi tersebut sebagai lembaga pelaksana hukum masih sebatas aparat di bidang kesehatan, kecuali pada program imunisasi yang sifatnya massal. Padahal penolakan imunisasi ini tidak hanya menyangkut masalah kesehatan tetapi juga masalah umum lainnya. Sehingga struktur yang ada kurang efektif dalam menyukseskan program imunisasi, strukturnya harus dibenahi dengan melibatkan unsur dari lintas sektoral lainnya baik pada program imunisasi yang sifatnya rutin maupun massal.

Substansi hukum meliputi aturan-aturan hukum, termasuk kaidah-kaidah hukum yang tidak tertulis. Yang dimaksud dengan substansinya adalah aturan, norma dan pola perilaku nyata manusia yang berada dalam sistem itu. Substansi hukum menyangkut peraturan perundang-undangan yang berlaku yang memiliki kekuatan yang mengikat dan menjadi pedoman bagi aparat hukum. Substansi hukum menentukan bisa atau tidaknya sebuah hukum dapat dilaksanakan. Substansi hukum dalam program imunisasi ini meliputi norma dan aturan yang mengatur tentang pelaksanaan program imunisasi. Dalam ketentuan pada Undang-Undang Nomor 36 Tahun 2009 tentang Kesehatan disebutkan bahwa setiap anak berhak memperoleh imunisasi dasar untuk mencegah terjadinya penyakit yang dapat dicegah dengan imunisasi. Pemerintah wajib memberikan imunisasi lengkap kepada setiap bayi dan anak. Pemerintah dan orang 
tua wajib mengusahakan agar anak yang lahir terhindar dari penyakit yang mengancam kelangsungan hidup dan/atau menimbulkan kecacatan. Imunisasi selain memberikan kekebalan dan mencegah penyakit kepada anak secara pribadi juga memberikan kekebalan secara komunitas atau kelompok. Setiap orang tua wajib memperhatikan kebutuhan anak untuk mendapat imunisasi dan itu adalah hak setiap anak. Dengan imunisasi, seorang anak tidak mudah terjangkit penyakit infeksi menular yang dapat menjadi sakit berat, meninggal ataupun cacat. UndangUndang Perlindungan Anak Nomor 35 Tahun 2014, disebutkan bahwa setiap anak berhak memperoleh pelayanan kesehatan dan jaminan sosial sesuai dengan kebutuhan fisik, mental, spiritual dan sosial.

Ketentuan pada Undang-Undang Nomor 4 Tahun Tahun 1984 tentang Wabah Penyakit menular menyebutkan bahwa barang siapa yang dengan sengaja menghalangi pelaksanaan penanggulangan wabah penyakit menular, diancam dengan pidana penjara selamalamanya satu tahun dan/atau denda setinggitingginya satu juta rupiah. Penyakit yang dapat dicegah dengan imunisasi merupakan jenis penyakit yang dapat menimbulkan wabah dan imunisasi merupakan cara pencegahan dalam upaya penanggulangan wabah penyakit menular. Pada kasus penolakan imunisasi ini dapat dikatakan sebagai upaya menghalangi pelaksanaan penanggulangan wabah penyakit. Norma atau aturan hukum yang mengatur tentang imunisasi belum sepenuhnya dapat diterapkan. Penerapan hukum salah satunya tergantung dari unsur hukum itu sendiri, sehingga apabila unsur hukum tidak dapat diterapkan maka kebijakan publik diharapkan mampu memberikan tindakan-tindakan yang lebih kontekstual dengan kondisi riil di lapangan atau masyarakat. Norma dan aturan hukum dalam pelaksanaan program imunisasi ini belum dapat dilaksanakan karena dalam hal ini belum ada kejelasan terkait kehalalan vaksin yang digunakan dengan pencantuman label halal. Selama ini penjelasan terkait kehalalan masih berupa fatwa dari MUI (Majelis Ulama Indonesia) yang masih menjadi perdebatan ditengah masyarakat. Yang mana masalah kehalalan juga merupakan hak bagi masyarakat umat Islam yang harus dihormati.

Budaya hukum merupakan sikap-sikap dan nilai-nilai yang memberi pengaruh kepada tingkah laku yang berkaitan dengan hukum dan institusi hukum, baik negatif maupun positif. Sikap manusia terhadap hukum yang lahir melalui sistem kepercayaan, nilai, pemikiran serta harapannya yang berkembang menjadi satu didalamnya. Unsur budaya dalam penerapan hukum sangat penting sebab ini kaitannya dengan bagaimana pemahaman masyarakat atas sebuah introduksi nilai yang hendak ditransformasikan oleh sebuah produk hukum atau Undang-Undang. Budaya hukum ini erat kaitannya dengan kesadaran hukum. Kesadaran hukum masyarakat dipengaruhi oleh faktor pengetahuan terhadap hukum positif, pengetahuan terhadap isi hukum, sikap hukum dan pola perilaku hukum. Pada pelaksanaan program imunisasi ini, masih ada masyarakat yang belum mengetahui hukum positip dan isi hukum yang mengatur tentang imunisasi. Sebagian masyarakat belum tahu bahwa orang tua wajib hukumnya untuk memberikan imunisasi dasar kepada anaknya. Masyarakat juga belum mengetahui bahwa menolak imunisasi ada sanksi hukumnya yang telah diatur dalam Undang-Undang. Masyarakat menolak imunisasi karena menurut kepercayaan masyarakat masih ragu terkait kehalalan vaksin yang digunakan, sehingga masyarakat masih enggan untuk mentaati hukum yang ada. Sikap hukum masyarakat dalam hal ini belum menerima hukum tersebut sebagai sesuatu yang bermanfaat atau menguntungkan, hal ini 
terkait dalam pola perilaku hukum masyarakat yang dapat dilihat apakah peraturan tersebut berlaku atau tidak dalam masyarakat.

Kepatuhan masyarakat terhadap peraturan perundang-undangan, mereka menganggap bahwa hukum tersebut sesuai dengan nilai-nilai yang hidup dalam masyarakat atau hukum yang dibuat sesuai kebutuhan masyarakat. Kasus penolakan imunisasi ini harus dilihat juga apakah hukum yang ada sudah mengakomodir kebutuhan masyarakat atau sudah sesuai dengan nilai-nilai yang hidup di masyarakat. Jangan sampai hukum yang dilaksanakan atau ditegakkan justru menimbulkan keresahan di tengah-tengah masyarakat.

Perlindungan hukum menurut Satjipto Raharjo adalah memberikan pengayoman terhadap hak asasi manusia (HAM) yang dirugikan orang lain dan perlindungan ini diberikan agar masyarakat dapat menikmati semua hak-hak yang diberikan oleh hukum. Menurut teori perlindungan hukum, masyarakat yang disasar adalah yang berada dalam posisi lemah, baik secara ekonomi maupun secara yuridis. Pada kasus penolakan imunisasi ini, anak dapat dikatakan mempunyai posisi yang lemah baik secara ekonomi maupun yuridis karena anak belum mempunyai kemampuan untuk kedua hal tersebut. Peran orang tua atau yang mempunyai hak asuh terhadap anak berpengaruh terhadap sejauh mana hak anak dapat diberikan. Setiap anak berhak memperoleh imunisasi dasar sesuai ketentuan yang berlaku untuk mencegah terjadinya penyakit yang dapat dihindari melalui imunisasi. Setiap anak berhak atas kelangsungan hidup, tumbuh dan berkembang, serta berhak atas perlindungan dari kekerasan diskriminasi. Orang tua yang tidak memberikan imunisasi kepada anak dapat dikatakan tidak memberikan haknya sebagai anak. Orangtua yang menolak imunisasi, sering kali tidak mengetahui atau menyadari bahwa imunisasi terkait dengan kesehatan komunitas. Orangtua kadang merasa cukup puas bila anaknya sehat. Mereka lupa, walaupun terlihat sehat namun menjadi pembawa (carrier) suatu penyakit dan dapat menularkannya kepada orang lain. Polemik program imunisasi ditimbulkan karena adanya konflik antara hak memilih individu dengan kepentingan publik. Meningkatkan dan mempertahankan kesehatan komunitas adalah lebih penting daripada memelihara hak individu untuk memilih bagi kepentingan tubuhnya. Apabila setiap individu di dalam komunitas diimunisasi, penularan penyakit dapat diputuskan dan kejadian wabah dapat dicegah. Pada kasus penolakan imunisasi ini penyebabnya adalah terkait keyakinan atau keraguan terhadap kehalalan vaksin, sehingga harus ada solusi agar hak-hak anak terlindungi.

Upaya-upaya yang telah dilakukan agar pelaksanaan program imunisasi anak dapat diterima dengan baik dalam upaya perlindungan hak-hak anak di Kabupaten Karanganyar, yaitu; (a) Melakukan pendekatan personal terhadap orangtua yang menolak imunisasi; (b) Melakukan pendekatan kepada tokoh masyarakat; (c) Advokasi; (d) Sosialisasi tentang vaksin dan imunisasi kepada masyarakat, kader kesehatan, aparat pemerintah yang ada di kabupaten, kecamatan maupun didesa, dan lintas sektoral; (e) Masyarakat yang menolak diminta membuat surat pernyataan penolakan beserta alasannya. Sedangkan upaya -upaya yang harus dilakukan antara lain : (a) Struktur dalam pelaksanaan program imunisasi harus dibenahi dengan melibatkan lintas sektor, hal ini karena penolakan imunisasi tidak hanya masalah kesehatan saja tetapi menyangkut masalah umum lainnya. Struktur yang terlibat di dalam pelaksanaan program imunisasi harus diberi kewenangan yang jelas dan pemahaman hukumnya sehingga mampu menjalankan tugasnya dengan baik.; (b) Adanya kebijakan publik yang mampu 
memberikan tindakan-tindakan yang lebih kontekstual dengan kondisi riil di lapangan atau masyarakat sehingga norma atau aturan dalam hukum dapat diterapkan dengan baik; (c) mensosialisasikan hukum positif dan isi hukum yang mengatur tentang program imunisasi kepada masyarakat sehingga masyarakat memahaminya. Masyarakat akan mengetahui manfaat dari hukum yang ada yaitu untuk memberi perlindungan kepada masyarakat yang akhirnya masyarakat mempunyai kesadaran hukum sehingga masyarakat berbudaya hukum.

\section{Simpulan}

Berdasarkan hasil penelitian dan pembahasan yang telah dilakukan, maka dapat diambil kesimpulan sebagai berikut:

1. Faktor-faktor yang menyebabkan terjadinya penolakan imunisasi adalah : (a) Struktur hukum dalam pelaksanaan program imunisasi belum mampu melaksanakan aturan yang ada dalam hukum karena struktur yang ada masih sebatas aparat dari unsur kesehatan dan keterbatasan kewenangan yang dimilikinya; (b) Norma atau aturan dalam hukum belum dapat diterapkan sepenuhnya di dalam masyarakat. Hal ini karena belum adanya kebijakan publik yang mampu memberikan tindakantindakan yang lebih kontekstual dengan kondisi riil di lapangan atau masyarakat. Masyarakat menuntut kejelasan terkait kehalalan vaksin yang digunakan dalam program imunisasi tersebut; (c) Sebagian masyarakat belum memahami hukum dan isi hukum tentang pelaksanaan program imunisasi sehingga masyarakat belum mengetahui manfaat dari hukum yang ada. Hal tersebut menyebabkan masyarakat belum mempunyai kesadaran hukum, yang pada akhirnya masyarakat belum berbudaya hukum yang baik.
2. Upaya-upaya yang harus dilakukan agar pelaksanaan imunisasi dapat diterima oleh semua masyarakat di Kabupaten Karanganyar antara lain : (a) struktur dalam pelaksanaan program imunisasi harus dibenahi dengan melibatkan lintas sektor, hal ini karena penolakan imunisasi tidak hanya masalah kesehatan saja tetapi menyangkut masalah umum lainnya. Struktur yang terlibat di dalam pelaksanaan program imunisasi harus diberi kewenangan yang jelas dan pemahaman hukumnya sehingga mampu menjalankan tugasnya dengan baik; (b) Adanya kebijakan publik yang mampu memberikan tindakan-tindakan yang lebih kontekstual dengan kondisi riil di lapangan atau masyarakat sehingga norma atau aturan dalam hukum dapat diterapkan dengan baik; (c) mensosialisasikan hukum positif dan isi hukum yang mengatur tentang program imunisasi kepada masyarakat sehingga masyarakat memahaminya. Masyarakat akan mengetahui manfaat dari hukum yang ada yaitu untuk memberi perlindungan kepada masyarakat yang pada akhirnya masyarakat mempunyai kesadaran hukum sehingga masyarakat berbudaya hukum.

\section{E. Saran}

1. Diperlukan adanya aturan terkait kewajiban pemberian label halal pada semua produk makanan dan obat-obatan termasuk dalam hal ini vaksin, hal ini mengingat negara kita mayoritas adalah muslim, yang mana masalah halal dan haram ini menjadi sesuatu yang mutlak yang harus dihormati oleh semuanya.

2. Diperlukan adanya kebijakan publik berupa Peraturan Daerah yang mengatur pelaksanaan program imunisasi di kabupaten. Peraturan daerah tersebut antara lain mengatur ruang lingkup, hak dan kewajiban baik masyarakat maupun 
pemerintah, serta mengatur bentuk sanksi yang akan diberikan bagi pihak yang tidak mentaati peraturan daerah tersebut.

\section{F. Daftar Pustaka}

\section{Buku}

Ariesto Hadi Sutopo dan Adrianus Arief. 2010. Terampil Mengolah Data Kualitatif Dengan Metode NVIVO. Jakarta: Prenada Media Group.

Mahlil Ruby. 2005. Peneliti Pada Pusat Kajian Ekonomi dan Kebijakan Kesehatan. Jakarta : FKM UI

Moleong dan Lexy J. 1989. Metodologi Penelitian Kualitatif. Bandung : Rosada Karya.

Ranuh, Suyitno dan Hadinegoro. 2014. Pedoman Imunisasi di Indonesia Edisi Kelima. Jakarta :Badan Penerbit Ikatan Dokter Anak Indonesia.

Soejono Soekanto. 2007. Pengantar Penelitian Hukum. Ctk. Ketiga. Jakarta : UI Press.

\section{Jurnal, Makalah dan Data Elektronik}

CDC, Smallpox Disease Overview, (On Line), 2007, dikutip 9 maret 2017, diakses dari: http//www.bt.cdc.gov/agent/smallpox/ overview/disease-fact-asp

Daniel Jolley and Karen M Douglas. “ The Effect of Anti-Vaccine Conspiracy Theories on Vaccination Intentions". PLOS. February 20. 2014.

Departemen Kesehatan. 2007. Profil Kesehatan Tahun 2006. Jakarta.

Health.kompas.com/read/2012/11/13/ 02284614/762 kasus difteri di jatim 29 meninggal, diakses pada 2 Juni 2016, jam 05.13 WIB

http://news.detik.com/berita/3240435/kasusvaksin-palsu-terbongkar-setelah-adabayi-sakit-setelah-divaksin/23 Juni 2016/diakses 04 Desember 2016.

http://www.kompasiana.com/leogultom/ imunisasi-dn-komunitas-anti-vaksin/08 maret 2016, diakses 29 Nopember 2016, pukul 05,05 WIB.

http://www.lintassolo.com/web/2016/06/ karanganyar-bebas-vaksin-palsu/, diakses 29 Nopember 2016, jam 19.30 WIB.

Jason Behrmann, "The Anti-Vaccination Movement and Resistance to AllergenImmunotherapy: A Guide For Clinical Allergists", BioMed Central Ltd. 2010, 17 March 2010.

Los Angeles Time, Public Health : Not Vaccinated, Not Acceptable?, (On Line), 2011, diakses 9 Maret 2017, Diakses dari : http://article. Latimes. com/2011/jul/18/opinion/la-oe-ropeikvaccine-20110718.

Pencatatan Dan Pelaporan Program Imunisasi Dinas Kesehatan Kabupaten Karanganyar Tahun 2015.

Pencatatan dan Pelaporan Program Imunisasi Dinas Kesehatan Kabupaten Karanganyar Tahun 2016.

Science Daily, How Poxviruses such as Smallpox Evade The Immune System, (Online); 2008, dikutip 9 Maret 2017, Diakses dari : http://www.sciencedaily. com/release/2008/01/080131122956. htm.

www.kompasiana.com/ryakair/preventifefektif-imunisasi-dalam-sketsa-sejarah, diakses pada 2 Juni 2016, jam 05.16 WIB. 
Dwi Rusharyati. Perlindungan Hak Anak dalam Pelaksanaan Program Imunisasi di Kabupaten ...

\section{Peraturan Perundang-undangan}

Undang-Undang Dasar Negara Republik IndonesiaTahun 1945

Undang-Undang Nomor 4 Tahun 1984 tentang Wabah Penyakit Menular

Undang-Undang Nomor 36 Tahun 2009 tentang Kesehatan.

Undang-Undang Nomor 35 Tahun 2014 tentang Perlindungan Anak.
Keputusan Menteri Kesehatan Nomor

1611 Tahun 2005 tentang Pedoman Penyelenggaraan Imunisasi.

Peraturan Menteri Kesehatan Nomor 1501 Tahun 2010 tentang Jenis Penyakit Menular Tertentu Yang Dapat Menimbulkan Wabah dan Upaya Penanggulangan

Peraturan Menteri Kesehatan Nomor 42 Tahun 2013 tentang Penyelenggaraan Imunisasi. 